\title{
Plays, Possession, and Rock-and-Roll
}

\author{
Political Theatre in Africa
}

\section{$\overline{\text { I. Peter Ukpokodu }}$}

\begin{abstract}
On 16 November 1977 the Kenya government banned any further public performances of Ngaahika Ndeenda [I Will Marry When I Want] by the simple act of withdrawing the license for any public "gathering" at the center. [Ngugi wa Thiong'o] was arrested on 31 December 1977 and spent the whole of 1978 in a maximum security prison, detained without even the doubtful benefit of a trial. They were attempting to stop the emergence of an authentic language of Kenyan theatre. (Ngugi 1986:58)
\end{abstract}

The historical realities of Africa have often times put theatres in contretemps with governments. In the I950s plays frequently attacked the prevailing colonial authorities. Productions that were overtly political were banned and the producers fined.' When most African countries achieved independence in the 1960 , the anticolonial theatre staged a euphoric celebration of freedom. The uhuru (freedom) cry blended with the articulated Negritude philosophy which had earlier helped kindle flames of nationalism. Jean-Paul Sartre saw this period of nascent freedom as a contingent stage in a total historical process-a moment in the black consciousness movement breaking through the bounds of its historical and sociological determination toward the recovery of its original, existential freedom. $\mathrm{He}$ described this moment as "the weak stage of a dialectical progression," a stage to be transcended on the way to "the realization of the human society without racism" (1963:70; and in Irele 1981:69).

But by the late I960s and early '7os, Africans were facing the grim realization that uhuru had not brought the anticipated political, social, and economic freedom. They found that uhuru had simply replaced white colonial masters with black colonial masters and that the latter could be more dangerous, an attitude aptly captured in Frantz Fanon's phraseology: "black skins, white masks." ${ }^{2}$ Some theatre artists could not help referring to these contradictions and they were banned. ${ }^{3}$ Theatrical performances that had 
luxuriated in the cultural epistemology, of Negritude began to wane as it became obvious that the new ontology of independence meant more than flag-waving patriotism. This critical soul searching was first reflected in dramatic writing. It was soon discovered that writing alone was not sufficient and that theatre practice itself had to change to address the mounting sociopolitical problems. By the late ' 70 s and into the ' 80 s experiments in African theatre the antagonism of the political establishment with the new amoebic forms necessary for survival in the rogos.

Though the Kamiriithu Theatre of Kenya, the Samaru Community Theatre Movement of Nigeria, the Zambuko/Izibuko of Zimbabwe, and the Refugee Theatre in Tanzania are genuine, creative, theatrical experiments in their own rights, they do seem to share some common theoretical base in the work of Paulo Freire, Frantz Fanon, and Augusto Boal. And hovering above them all is the spectre of Bertolt Brecht. Relevant theories from these men are slashed, merged, adapted, and built into native theatrical experiments that have been attacked by the political establishment but embraced by an ever-growing audience. Freire's main theoretical contribution is in his "conscientization"-a term which refers to the process of learning to perceive contradictory social, political, and economic realities that engender oppression and against which action must be taken (Freire 1972:15). Conscientization enables an oppressed people to generate their own sociopolitical consciousness along a revolutionary path. The theory propounded by Boal is similar; the real difference is that while Freire concerned himself with education in all its facets, Boal focuses on theatre as a weapon in class struggles. Adherents to Boal's methods are in the end able to create their own theatre to overcome oppression. Current theory adapts Bertolt Brecht's idea that theatrical experiences be translated into practical action in the real world by the spectators. The audience, the theatre, and the society must be invariably linked. Theatre must be extroverted, that is, concerned with the social problems that people must question and change. Multimedia production is encouraged.

\section{The Kamirithu Theatre Experiment in Kenya}

It is a Kenyan government policy that a drama group register with the government. Even after a group has been registered, it must obtain a license to perform each play. In March 1982 the government of Kenya revoked the license for Kamiriithu Community Education and Cultural Center saying that the people were being "misled into cultural activities that had nothing to do with development." It proceeded to ban all theatre activities in that area. Then on 12 March 1982 , a day after the Kamiriithu Theatre had been officially banned, three truckloads of heavily armed policemen razed Kamiriithu's open air theatre. In response to widespread bitter criticism and condemnation by national and international communities, the President of Kenya, Daniel Arap Moi, said in public speeches that the Kamiriithu was culpable for "teaching politics under the cover of culture" (in Ngugi 1983:44-47). As in 1977 when I Will Marry When I Want was banned and Ngugi wa Thiong'o, one of the coauthors, was incarcerated, the government was attempting to stop the emergence of an authentic language of Kenyan theatre. What was this "authentic language" that set the Kenyan theatre on a collision course with the Kenyan government?

The language-a metaphor for form and content-is the one developed at the Kamiriithu Community Education and Cultural Center, where the theatre was organized by the rural populace who acted and produced plays under the directorial expertise of Ngugi wa Thiong'o. Central to the idea 
1. E 2. "Africans traditionally performed in open spaces under natural light. The members [of Kamirithu Theatre] see an empty and free space as reconnecting with the broken roots of African civilization." Here, a circle of spectators in Oyo, Nigeria, establish the space for a performance in which they are free to join.

Kamirithu and Samanu experiments have used this traditional form to make sociopolitical comments. (Photo by Ajayi) is the use of the indigenous language to create dramatic situations in which the history of the people is linked to the current sociopolitical situation. This apparently is innocuous enough. What native government would prevent its people from reenacting their history, especially if that history is anticolonialist?

Central to Kenya's history is its engagement in a guerilla war for liberation from Britain. The bloody Mau Mau War, as this struggle for independence is often referred to, was fought ostensibly to bring uhuru to the people. The freedom envisaged was one in which the people would get back their farm lands and goods. This was what the native political leaders of the struggle for independence told the people and this was what made the people fight with such intrepid determination. Thousands died, with some families losing all their male children, a great blow for a tradition which holds that only male children foster the immortality of the family lineage. Independence was eventually achieved but the hope of the masses was betrayed as the new rulers-black native Africans-formed an elitist group that simply took over the structure of dominance and wealth vacated by the colonial administration.

Decades after independence from Britain, nothing in the sociopolitical establishment of the country had changed to make life better for the majority. Indeed, things were getting worse. Ngugi decried this betrayal of uhuru in most of his works written in English. With the Kamiriithu Theatre, he began to educate the masses to adopt a critical attitude toward Kenyan society. The new theatre used the native language, not English. In the preface to The Trial of Dedan Kimathi (1976), Ngugi and his coauthor Micere Mugo wrote a literary manifesto advocating a radical change in the attitude of African writers. They were called upon to fight on the side of the people against class enemies. Ngugi and Micere called for a revolutionary theatre that would truly depict "the masses in the only historically correct perspective: positively, heroically, and as the true makers of history." They defined good theatre as being on the side of the people, "that which, without masking mistakes and weaknesses, gives people courage and urges them to higher resolves in their struggle for total liberation." But they failed to ask themselves how this revolutionary theatre was going to urge people to higher resolves in a foreign language. Moreover, Ngugi pointed

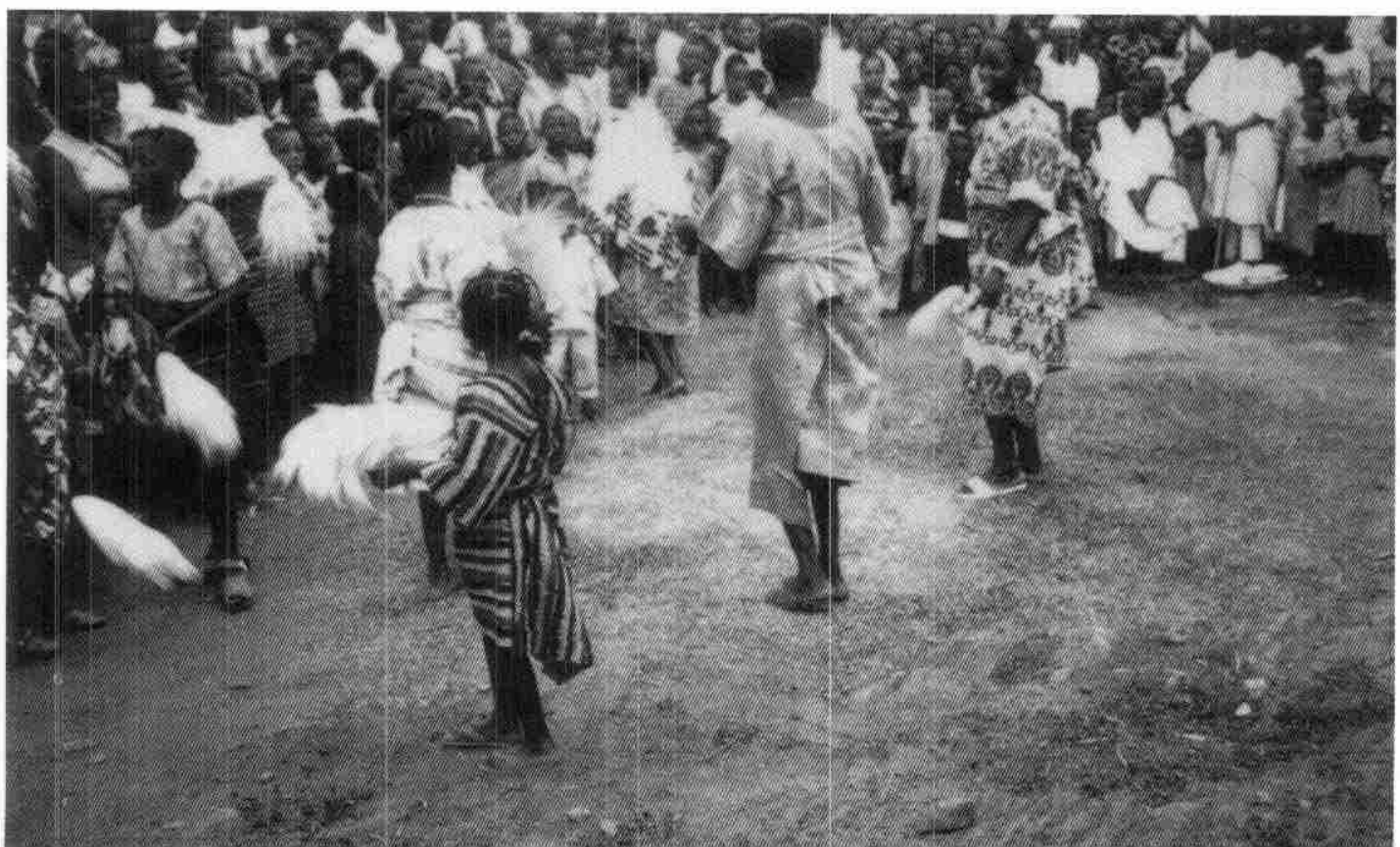


out contradictions in the use of English onstage. Some characters speak a poetic and impeccable Queen's English, reminiscent of T.S. Eliot. The audience is supposed to believe these characters are speaking an African language. But this illusion is broken when these same characters fall back into their African languages when it comes to singing. "So they do know African languages! The illusion that in speaking English they were really speaking an African language is broken. The realism in theatre collides with the historical reality it is trying to reflect" (Ngugi 1986:43).

Kamiriithu Theatre was a pathfinder in the use of Gikuyu, an indigenous Kenyan language. For Ngugi, it was an "epistemological break" with his past. The question of audience settled the problem of language choice, and the language choice settled the question of audience. But the use of Gikuyu had other consequences in relation to other theatre issues: content, performers, auditions, rehearsals, performances, reception, and theatre itself as a language. Members of the Kamiriithu Theatre were very particular about the use of language once it was decided that Gikuyu would be the language of the production:

They were concerned that the various characters, depending on age and occupation, be given the appropriate language. "An old man cannot speak like that" they would say. "If you want him to have dignity, he has to use this or that kind of proverb." Levels of language and language-use and the nuances of words and phrases were discussed heatedly. (Ngugi 1986:54)

In terms of theatre architecture, the Kamiriithu Theatre was an empty space, not a proscenium theatre like those found in cities and universities. Africans traditionally performed in open spaces under natural light. The members saw an empty and free space as reconnecting with the broken roots of African civilization. Ngugi writes:

It was the peasants and workers from the village who built the stage: just a raised semi-circular platform backed by a semi-circular bamboo wall behind which was a small three-roomed house which served as the store and changing room. The stage and the auditorium-fixed

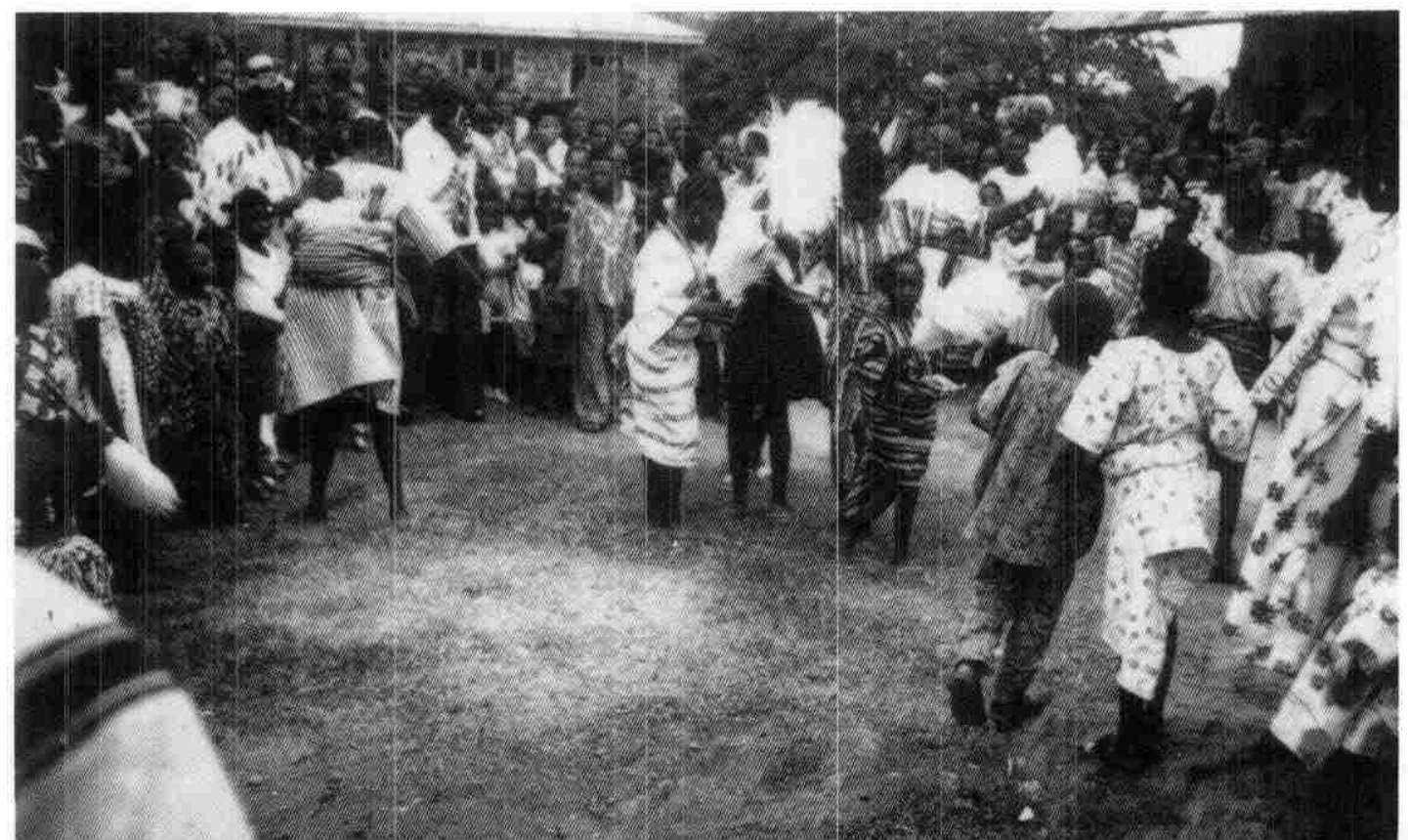


long wooden seats arranged like stairs-were almost an extension of each other. It had no roof. It was an open air theatre with large empty spaces surrounding the stage and the auditorium. The flow of actors and people between the auditorium and the stage, and around the stage and the entire auditorium was uninhibited. Behind the auditorium were some tall eucalyptus trees. Birds could watch performances from these or from the top of the outer bamboo fence. And during one performance some actors, unrehearsed, had the idea of climbing up the trees and joining the singing from up there. They were performing not only to those seated before them, but to whoever could see them and hear them-the entire village of 10,000 people was their audience. (Ngugi 1986:42)

This theatre, built and run on a self-help basis, had a seating capacity of more than 2,000 persons (Ngugi 1981:75-77).

The Kamiriithu Theatre followed the form of African storytelling, using mime, music, and dance. The storytelling format allowed an active verbal and tactile relationship between performers and spectators. More than this, it seems to have had a didactic purpose since it permitted telling stories about the history of the people. The theatre became a continuous learning process for its members: learning Kenyan history; what happens in factories, farms, and plantations; developing the native tongue; and learning anew the elements of traditional African theatre-song, dance, and mime. From the very beginning the Kamiriithu Theatre was aware of its mission to educate the people; it was part of a larger educational and social center:

Plays would serve three main purposes. They would serve as entertainment and collective self-education; they would form follow-up reading material for the new literates; and they would raise money to finance the other programmes, material culture and health for instance, and to meet the day-to-day expenses like chalk, writing materials and electricity bills. (Ngugi 1981:76)

Mime, song, and dance are central to most African rituals and ceremonies that celebrate the rites of passage-birth, circumcision, marriage, deathand to other activities like planting, harvesting, rain-making, and welcoming the new year. Even daily speech among peasants is interspersed with song; song, dance, and mime are an integral part of daily conversation and activities. Kamirithu tried to incorporate these elements of form as part of the structure and movement of the performers. "The song arises from what has gone before and it leads to what follows. The song and the dance become a continuation of the conversation and of the action" (Ngugi 1986:45). Often, the past and the future are recreated through song and dance and mime. In I Will Marry When I Want these techniques are used a lot. The play asks many questions about the nature of Kenyan society, generating heated discussions among both participants in the production and the ever-widening circle of audiences. "Land and freedom. Economic and political independence. Those were the aims of their struggle and they did not want Ngaahika Ndeenda to distort them" (Ngugi 1986:45). The content is the evolutionary history of oppression in Kenya from foreign masters to native masters: how the future of Kenyan children was already hopelessly mortgaged by living Kenyan exploiters. So past, present, and future are linked in a chain of sorrows in which the future will be worse than the present just as the present is worse than the past.

Scripting, rehearsing, and production at the Kamirithu were a collective responsibility. For example, Ngugi wa Thiong'o and Ngugi wa Mirii were 
given the task of producing a "working script" for I Will Marry When I Want. When they brought the outline, the peasants for the next two months kept on adding to and altering it. Though there was a director (Kimani Gecau), the project was a collective community effort with peasants and workers seizing more and more initiative in revising and adding to the script, in directing dance movements, and in the production's general organization. Collective democratic decisions on the basis of frank criticism, self-criticism, and hard work became the organizing principle that gradually emerged as the cornerstone of the Kamiriithu Theatre. The readings, the discussions, and the rehearsals sometimes on Saturday, but always on Sunday afternoons were timed to keep in rhythm with the lives of the people. (Sunday afternoons were chosen to avoid interfering with church obligations in the mornings.) Acting was done by the peasants themselves and people who actually experienced particular aspects of the history were encouraged to be in the cast. There was emphasis on active participation both during rehearsals and in production. The rehearsals were all in the open, attracting an ever-increasing crowd of spectators and an equally great volume of running commentaries.

Some people in fact were recruited into the acting team after they had intervened to show how such and such a character should be portrayed. The audience applauded them into continuing doing the part. Perfection was thus shown to be a process, a historical social process, but it was admired no less. On the contrary they identified with their perfection even more because it was a product of themselves and their collective contribution. It was a heightening of themselves as a community. (Ngugi 1986:57)

When I Will Marry When I Want opened to a paying audience, it was an immediate success. People came from afar in busses and taxis; it was like a collective festival. Audience members called themselves by the names of their favorite characters and the language of the play became part of the people's daily usage and frame of reference. There were some touching moments. Ngugi remembers one Sunday-all performances were on Sunday afternoons only-when the rain drove people from the theatre to seek shelters under trees and roofs. When it stopped, the actors resumed and the theatre was as full as before. "The performance was interrupted about three times on that afternoon but the audience would not go away. The people's identification with Kamiriithu was now complete" (Ngugi 1986:57-58).

The Kamiriithu Theatre witnessed adverse conditions when I Will Marry When I Want was banned and Ngugi wa Thiong'o was incarcerated. But in November I98I members regrouped for a production of Maitu Njugira (Mother Sing for Me). The message clearly pointed out the history of exploitation, of salvation by Mau Mau liberators and of hope betrayed, of the march forward and of setbacks in Kenya. This time the production was to take place in Nairobi, the capital city, so that the government could feel the heartbeat of the people's theatre. Kamiriithu Theatre was denied access to the National Theatre. The group held rehearsals at the University of Nairobi for over Io,000 people before the university authorities were instructed to refuse them the use of the premises. This was swiftly followed by a government order that outlawed Kamiriithu Community Education and Cultural Centre and banned all theatre activities in the entire area. And then came the physical destruction of the Kamiriithu Theatre, the harassment of its leaders, and the escape into exile of most of them.

Although short-lived, the Kamiriithu Theatre began a chain of powerful 
sociopolitical influence. It taught people Kenyan colonial and neocolonial realities by juxtaposing historical events with contemporary. Says Wanjiru wa Ngigi, a secretary and mother, in an interview with The Standard of Friday, 29 January 1982, "Knowing more about my past has made me more sensitive to my present situation and that of my future and the future of my children" (in Ngugi 1986:60). It was this kind of awareness, this conscientization of erstwhile carefree people, that the government vehemently opposed. The theatre embodied an alternative vision of existence and its physical destruction further alienated the people from the government. The President of Kenya tried in vain to improve his image by building a polytechnic where the Kamiriithu Theater once stood (Ngugi 1986:6I). But the message of the Kamiriithu could not be killed; after its first production people from other communities came to enquire how they could start similar cultural ventures:

Before long, we had received one delegation from Gikaambura village in Kikuyu, and another from Kanyaariri, on how they too could start a similar community cultural project. Another group of teachers came from Nyaandaarwa North and they too wanted to start their own Kamiriithu. (Ngugi 198 I:47)

Kamiriithu was the beginning of a peasant/worker theatre movement that spread beyond Kenya. The Ministry of Education and Culture in Zimbabwe invited the Kamiriithu Theatre for performances and workshops sessions; the Kenyan government never allowed the group to go.

The movement now exists in two forms: as a cultural wing within Kenya; and as a political underground movement within but mostly outside Kenya. Theatres have sprung up in various parts of the country, using the Kamiriithu techniques but without overt political statements. Teachers, both at the schools and the colleges of higher education, have especially contributed to this effort. Some of the productions have been organized surreptitiously in drinking places and openly in market areas. But the government has found ways of silencing some of the performances and any gathering it detests. For example, in July 1990, after attending a "meeting" (euphemism for political productions) in a bar in Nairobi, Edward Oyugi, a lecturer at Kenyatta University, and seven others were arrested and subsequently charged with intending to "bring into hatred or contempt or excite disaffection against and intended to procure by unlawful means the overthrow of the Kenyan government" (Graham-Yooll 1990:38). In the Kero Valley where villagers had participated in a cultural performance in March 1991, the Minister for Energy, Nicholas Binott, had been sent by the government to sternly warn the people. Journalist Machario Gaitho and his student intern Julius Bargorett were savagely beaten by the police while attempting to cover the meeting between Binott and the villagers. On 25 March I99I, a Kamiriithu performance was organized on the streets of Nairobi itself. The police broke up the performance under the pretext of carrying out a raid on illegal "street traders in Nairobi." Photographers Charles Maisha and Kavyu Mutinda of the Standard newspaper were beaten by the police while attempting to photograph the confrontation (Graham-Yooll 1991:37).

Most members of the Kamiriithu have joined Mwakenya, a clandestine opposition political group in Kenya. ${ }^{4}$ Denied the right to perform publicly, members of Mwakenya have begun underground publications of which Mpatanishi, Mzalendo, and Pambana are the most visible. Mwakenya-an acronym for Muungano wa Wazalendo wa Kukomboa Kenya (Union of Pa- 
triots for the Liberation of Kenya)-is national in membership and modeled after the Mau Mau, the resistance group that waged guerrilla warfare against the British.

Exiled members of the Kamirithu Theatre are now more overtly political than they were in Kenya. They have drawn international attention not only to their own plight but to the overall sociopolitical situation in Kenya. Micere Githae Mugo, now exiled in Zimbabwe, is carrying forward the Kamirithu ideal of empowering all African women. She is promoting continental awareness of the political, economic, and social plight and condition of African women through conferences, writings, performances, and trade unionist activities.

The majority of women belong to the masses, mainly the peasantry but also petty traders and factory hands who lead incredibly poor and disadvantaged lives, who live on the periphery of the African world politically and economically, and who suffer incredible difficulties through disease, illiteracy and poverty. Now when you consider that women make up over 52 percent of the continent's population, we are saying that we have really to begin worrying about the position of the majority of our women, roughly 80 percent, and those, to me, are my worry because of the creativity that is being submerged and because they are being absolutely excluded from any developmental process. (Mugo I990:19)

Since her arrival in Harare, Zimbabwe, Mugo has used theatre in unionist activities not only to cut across gender problems but to "address the gender issue and put women on the map." She portrays and calls for the destruction of that brutal political and patriarchal structure which, "through socialisation and [ . . . culturalisation" of women makes it "look virtuous [for the women] to be submissive" (Maja-Pearce I990:20).

Outside Africa, Kamiriithu exiles have been actively drawing attention to the Kenyan situation. After conducting Kamiriithu workshops at the University of Zimbabwe and seminars on theatre for peasants at the Institute of Development Studies at Harare, Ngugi went to London and, with fellow exiles, formed the CRPPK (Committee for the Release of Political Prisoners in Kenya). In London he produced The Trial of Dedan Kimathi, much to the chagrin of the Kenyan government, which had unsuccessfully tried to persuade the British government to suppress the production by discrediting it as communist propaganda. Shortly after that production he went to Japan to supervise the staging of I Will Marry When I Want in Japanese, directed by another Kenyan exile, Cyrus Gordon Mwangi.

Since 1988, Ngugi has been preoccupied with bringing together the various dissident groups in exile to form a united front in support of the struggle carried on by Mwakenya. He became the chair of Umoja Wa Kupigania Democrasia Kenya (United Movement for Democracy in Kenya). Umoja is made up of Muungano wa Demokrasia Kenya (MDK) in the United States; Kenya Democratic Alliance (KDA) in Norway; Ukenya, in Britain; Committee for Democracy in Kenya (CDK) in Sweden; and in Africa, Kamati ya Ukombozi Kenya (Kaukenya), and Patriotic Alliance of Kenyans (PAKE). Umoja solicited an international outcry against the Kenyan government when in July 1990 paramilitary forces massacred demonstrators at a prodemocracy rally in Kamukunji in Nairobi. Umoja also supports a new group, Forum for the Restoration of Democracy, which the Kenyan government declared illegal as soon as it was formed in September r991. Within the same period the Attorney General 
of Kenya banned the British barrister, Geoffrey Robertson, QC, from appearing in a Kenyan court to defend members of the Kenya Law Society who advocate the right to form political parties (Graham-Yooll 1991:37).

Umoja conferences, in spite of their avowedly political nature, are still marked by theatrical performances, poetry readings, and revolutionary songs. Even at the launching of the organization performance was an integral part of the ceremony. But the highlights are usually the political statements and plans. Just as at the first conference, delegates continue to examine the problems experienced by the various organizations-lack of discipline, lack of instant communication among different groups, isolation from the struggle in Kenya, factionalism and "anarchic tendencies." To overcome these difficulties Umoja has since formed a central secretariat with branches worldwide. Umoja sees itself as an "anti-imperialist organisation wholly committed to the restoration of [Kenya's] national sovereignty, the building of a truly democratic Kenya and the restructuring of the economy for the social progress of the Kenyan people. Umoja is not a new party but a support movement for the struggle at home" (Azad r988:68-69).

\section{The Samaru Community Theatre of Nigeria}

The Samaru Community Theatre is an experiment by the Ahmadu Bello University. It uses theatre as a vehicle for promoting social awareness among the rural communities, especially to educate the people about health, agriculture, education, cooperatives, and self-development. The real focus in this experiment is the active participation in the theatrical process by the people themselves. This involvement is an attempt to avoid the shortcomings that brought the demise of earlier experiments, like the Guerilla Theatre of Nigeria whose performances reached their zenith in 1965 .

The Guerilla Theatre was organized by Wole Soyinka. Begun in 1963 , it presented overtly political satiric sketches put together by well-rehearsed university theatre artists during political campaigns. The sketches were loosely scripted, allowing room for improvisation. Usually, members of the group would block off a street and one of them would announce to the people in the manner of an African town crier that an important theatrical event was about to take place. Ignorant of what was going to happen, the crowd would gather and Guerilla members would quickly present powerful sketches dealing with the political impropriety and social corruption of some well-known political figures and social elites. Its radical political attacks kept the group always on the run. The Guerilla Theatre never really got a good audience. It failed because the sketches were performed in English before a predominantly indigenous Yoruba audience and because there was no attempt made to involve the actors and audiences in a critique of the productions (Ogunbiyi I98I:46). The series of military coups in 1966 and the incarceration of Wole Soyinka from 1967 to 1970 finally ended the Guerilla Theatre. The Samaru experiment rose from the ashes and mistakes of the Guerilla Theatre. ${ }^{5}$

Rather than attack and lampoon governments and politicians, Samaru theatre sketches initiate action for developing rural communities. The defining yardstick in the experiment is the conscious use of the performing arts to bring about or reinforce a process of social change-changes in selfconcept, attitude, awareness, and behavior. The overriding focus is to make people understand and change their existing situation and/or to understand and deal with changes in their lives produced by external influences. Says Tar Ahura, one of the project leaders of the Samaru Community Theatre Movement: 


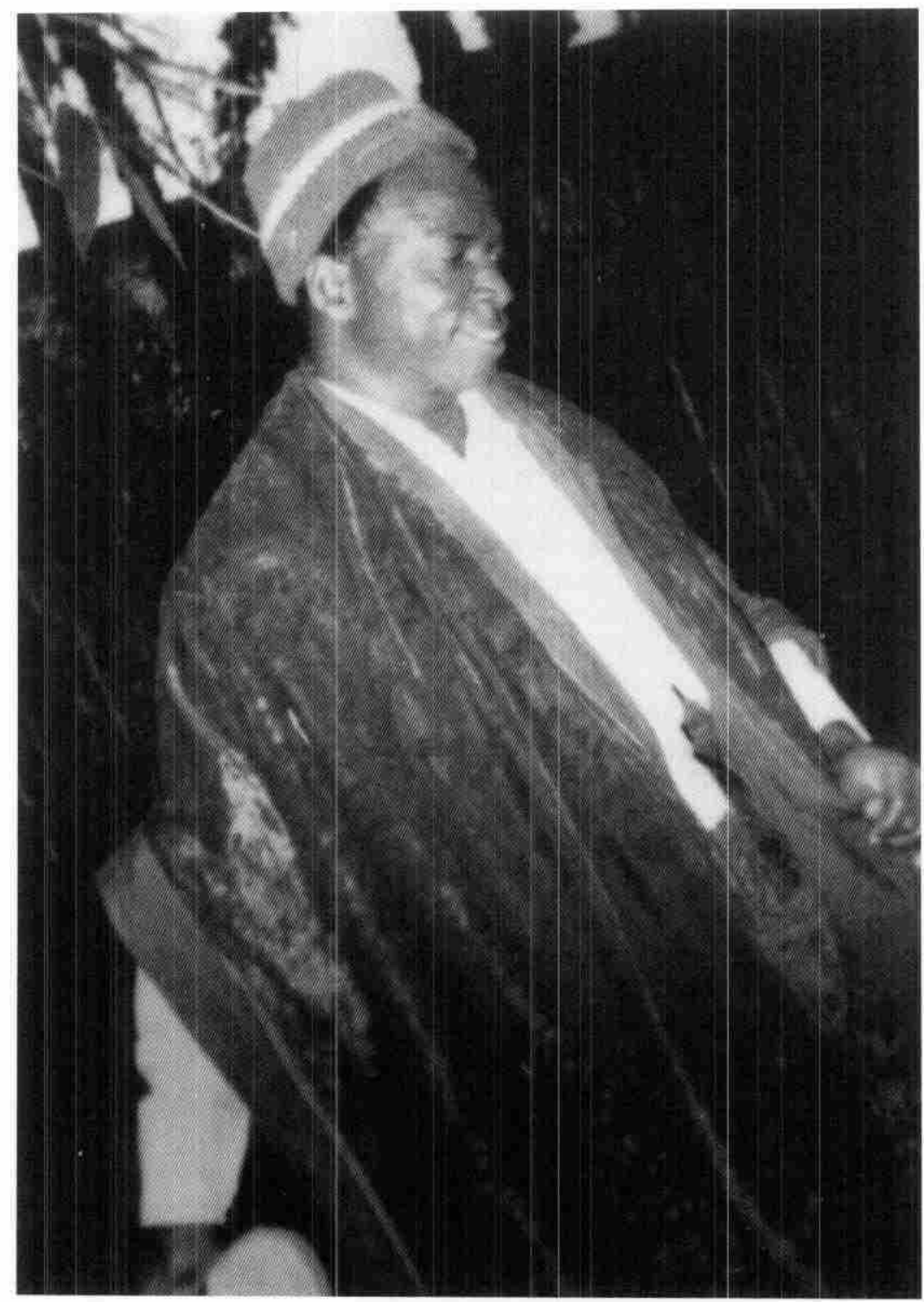

3. Chief Oko, the community leader of Makurdi, Nigeria, begins a performance staged by students and local people in 1990 by dancing. The fan in his right hand is a symbol of authority. (Photo by C. Achugbu)
Theatre must [. . .] take its appeal direct to the depressed rural man. It must be recognized that real revolutionary power lies in the rural masses. What they lack is the organizational capacity coupled with their loss of confidence in their abilities. For theatre to be relevant in circumstances of this nature, it must above all things rely on revolutionary aesthetics. (1986:n.p.)

The revolutionary aesthetics of theatre as a tool for development involves a process of information research, analysis, playmaking, discussion, and follow-up.

The whole process begins when the theatre workers go into a village to identify problems in the area-social, political, or economic. Interviews are held with the villagers themselves. Occasionally, this process proves difficult if the people have lost hope in the government and tend to see any- 
one from an institution or an agency, including theatre workers, as agents of the superstructure that does not care about their welfare. To overcome this resistance, the participants first visit the leader, the head of the community. If he is satisfied with the purpose of the planned interviews and the overall value of the project to his community, the research goes smoothly. The data collected in the interviews will form the basis of the drama. Once the problems in the community have been identified, the theatre workers come together to analyze them based on their own knowledge of such problems as well as the knowledge and beliefs of the villagers. Occasionally, problems that run counter to those presented by the villagers are posed. This dialectical opposition helps in the playmaking and in postproduction discussion.

Once a topic is selected, Samaru members outline a drama without involving the villagers. The performance is comprised of dramatic sketches, role-playing, music, and dance. The techniques and skills used vary but generally involve improvising, acting, composing, singing songs, learning some local dances, and making and learning to operate puppets. The traditional art of storytelling is also employed. Only theatre workers who understand the language of the community are given roles, along with local participants. After every rehearsal, the actors and the villagers discuss the performance and make suggestions as to what should be added or removed. Involving the community in these postrehearsal discussions increases their self-confidence and ensures greater mobilization and participation.

The physical theatre used for both the rehearsals and performances is simple-the street. Cast members block off a dead-end street, erect a tarpaulin backdrop, and perform in the dust, facing the sun for illumination. The standing audience forms a semicircle.

Through the process of rehearsal and criticism, a finished drama is created. A day and a time are fixed. Community people do the publicity, using indigenous systems of disseminating information. People gather to watch the drama and afterward the leader of the community and his deputies open a discussion of the problems raised in the play and the value of the solutions offered.

Postproduction evaluation does not end the work. To ensure that ideas lead to concrete actions, theatre organizers keep up the pressure and enthusiasm by repeated visits and reminders. Community organizations and age groups are entrusted with keeping the momentum going. If there is no resultant action, the project is not considered a success.

The Samaru Community Theatre Movement is indirectly funded by the government since it is based in a government-owned university. This relationship places some strain on how radical the project dares be. In a continent where huge sums of money are spent to perpetuate hero worship of trigger-happy leaders and where the judiciary is a puppet of the governments, a development-oriented theatre that hopes to survive censorship, proscription, or total annihilation does well to tread softly. It is in recognition of this that Hansel Eyoh, a coordinator of a theatre-for-development project in Cameroon says that "while the popular theatre need not become so marginalized as to dissipate its efforts, its radicalization ought to be done in such a way as to ascertain its survival, rather than exposing it to repression" (I984:n.p.).

But neither Samaru nor the villagers who now knew the power of theatre could tread softly for long. Samaru productions had actively begun in 1979 and from 1980 to 1982 had spread to major cities like Sokoto, Zaria, and Kano. The first test of the new awareness wrought in the people by the theatre was a baptism of blood. Some powerful Nigerian politicians, govern- 
ment officials, and traditional rulers sold the fertile lands of poor farmers in Bakolori village to an Italian company without consulting the villagers. The farmers refused to give up their land. In an April 1980 encounter with police who had been sent to forcibly remove them, hundreds of farmers and their families were massacred. The Samaru theatre had "conscientized" people into questioning formerly accepted modes of being, but the theatre could not be directly held responsible for what had occurred. According to Tar Ahura, one of Samaru's foremost leaders, the Nigerian rural masses are potentially volatile; once they are worked into consciousness of their own plight, they want to do something radical about it. ${ }^{6}$

To survive thinly veiled government anger that would cut off funds, and the general economic depression in Nigeria throughout the entire decade of the 1980 s, the Samaru theatre had to scale down experiments that were deemed antigovernment. After a repressive military elite staged a coup d'etat in December 1983, Samaru began to focus more on nonpolitical developmental issues: family planning, prostitution, divorce, drunkenness, health, modern agriculture, and the value of Western education and literacy.

But even these experiments were adversely affected by the intolerant military regimes, first of General Buhari and later of General Babangida. Since 1987, the latter regime has been confronted annually by one form of university student unrest or the other. Most of the riots are violent, with lives and property lost. In the second week of October 1991 a riot in Kano (in the catchment area of the Samaru theatre) brought the death of several people and the destruction of two important market centers. As of November I99I, a curfew is still imposed on the city. During such riots or unrest the universities are compulsorily shut down. The frequent closures of the universities have adversely affected the Samaru experiment for once, the universities are closed the theatre and its staff are not allowed to operate.?

Moreover, the much dreaded Decree 2, 1984, of the military regime of Nigeria, which permits indefinite detention without charge or trial for reasons of national security, has been most effectively used against the universities. Almost any issue or activity that is socially and politically important to the people has been curtailed by this decree. This has severely hampered the Samaru theatre experiments, for even religious issues cannot be addressed. Samaru and its university environs have often been the center of violent clashes with religious fundamentalists. Some members of Samaru have moved their political theatre from the streets into their homes; now experimenting with living-room productions-theatrical events performed in the living room of a member, sometimes in a large bedroom, for invited audiences only. Performing for known audiences is the only way to escape the government spies who are said to be almost everywhere. Expectations are high that the Samaru theatre will unleash their political activism with renewed vigor when military government ends in October 1992.

\section{Political Prophecy}

The hostility of the Nigerian government to radical forms of theatrical expression, and the menacing presence of Decree 2 , have made sociopolitical dramatists more creative. While some have turned to "poetic recitations"-one to three-person "reader's theatre" with loosely tied episodes, well rehearsed but advertised as poetry, with actors pretending to read from a book-others have turned to religion as an avenue for expression. They have become seers, prophets, and apostles who, "possessed by spirits," are able to dramatize and make sociopolitical statements without government prosecution and persecution. ${ }^{8}$ 
4. To escape government spies, some members of Samuaru have moved their political theatre from the streets to private living rooms for invited audiences only. This photo and the next four are from a livingroom performance staged in Zaria, Nigeria, in 1991. Here, a Political Leader (acted by Danjuma Alkali) dreams of Nigeria as he sleeps beneath a map of his country. (Photo by Alhaji Sule Dan Sokoto)

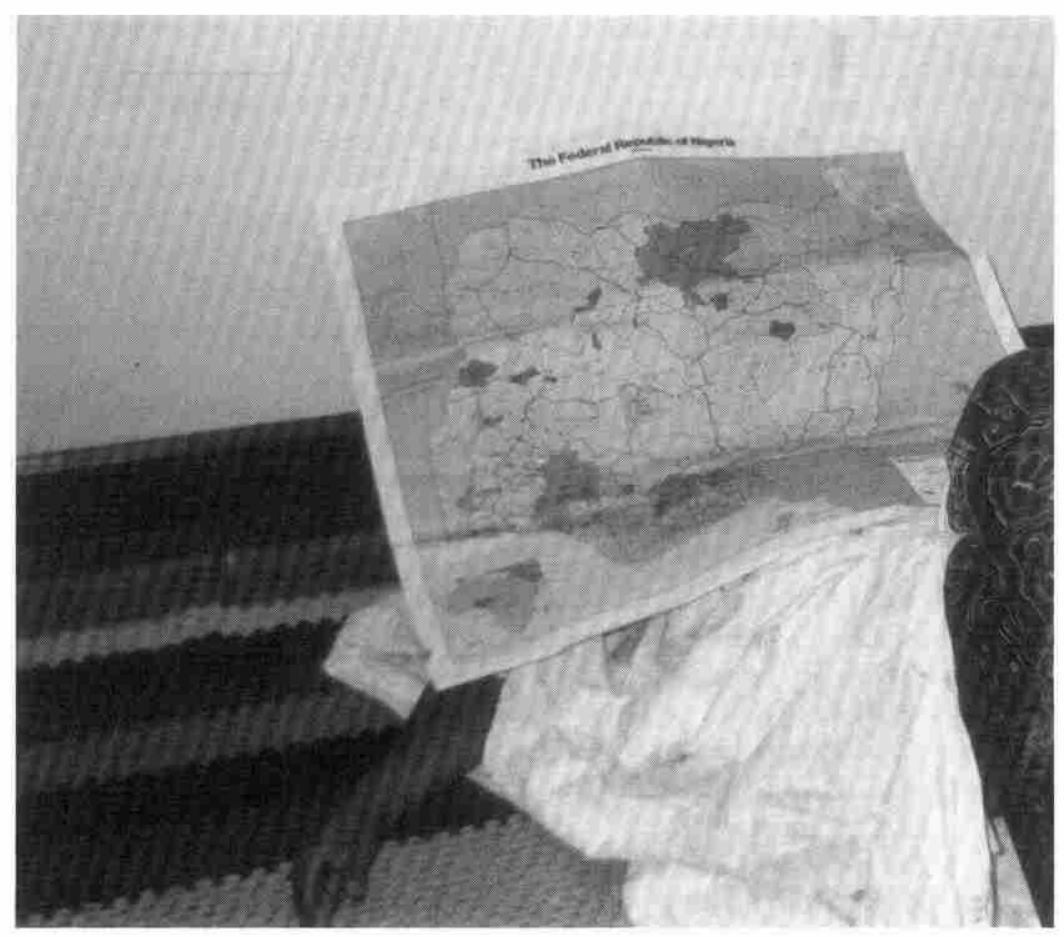

Although religious people may be reluctant to equate worship with theatre, they have always been aware of the theatrical elements in religious ceremonies, including costumes, props, and performance styles (Jules-Rosette 1988:I4I). Performers go into ecstasy and they are believed inspired or possessed by a spirit, a Mami Wata (female water spirit) or jinn. The use of ecstatic prophecy is an ideal poetic license in periods of sociopolitical persecutions. The African cultural context makes spirits, including ancestors, higher and more powerful than humans. They can inhabit whom and what they choose and have complete freedom of speech; if a spirit enters a person and she utters what the spirit wants, is that human being then capable of questioning the spirit? Dare she tell the spirit to shut up? Mami Wata is particularly feared as she can be very good or very bad. No political leader would dare question a Mami Wata. Therefore, performances based on spiritualism are a safe alibi for contemporary dramatists. Religion is a very touchy issue in Nigeria, especially between the Moslems and the Christians in the northern part of the country, and no government could prosecute a religious-based event without accusations of favoritism followed by riots.

When possessed-for real or not-the costumed dramatist acts out the roles of a devil, a witch, or an evil person who is responsible for some social and political problem. For example: a highly placed politician or law enforcement agent who receives bribes; a political thug who maims or kills an opponent; an employment agent who seeks carnal pleasure from the opposite sex before hiring; an avaricious politician who uses human blood in a satanic ritual to achieve power and money; an armed robber who has the protection of well placed politicians or law enforcement agents; or an evangelist who has sold out by supporting government misdeeds.

While some of these "holy" or "spiritual" events are held in school halls 


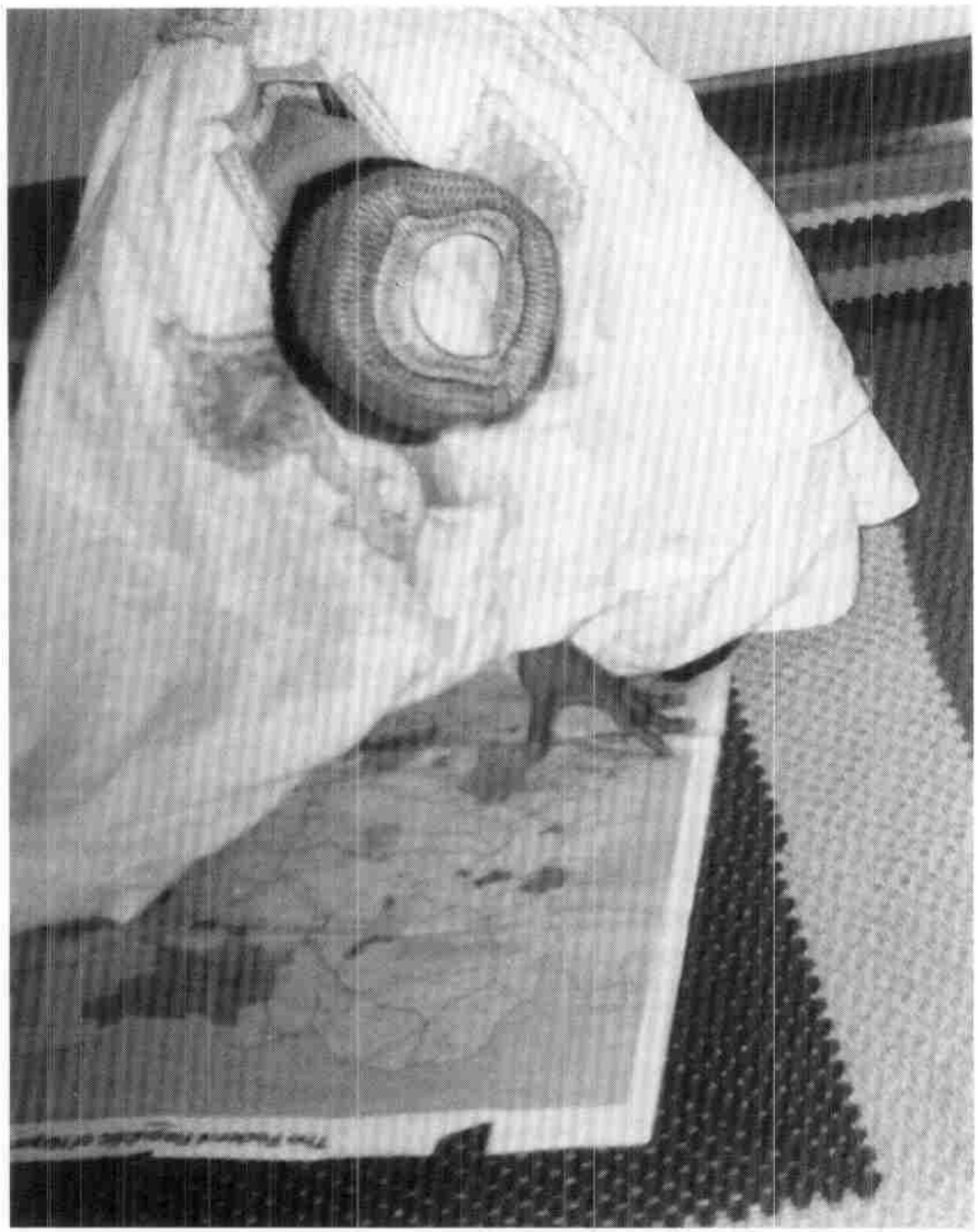

and large classrooms that are usually vacant on weekends, most take the form of street theatre: they are performed in open areas with a lot of didacticism, music, and considerable flair. Performances are rehearsed, although room is given for other "prophets" and "possessed" audience members who may be inspired to contribute to the ongoing drama. One such contribution made it to the national news media when an ecstatic woman spoke of how the spirit told her that a member of the congregation must marry her; the following weekend the would-be husband went into a trance, narrating the stern warning of the spirit not to marry the lady involved in the previous ecstasy. Bennetta Jules-Rosette, who has witnessed similar occurrences in some other African nations, explains that:

Prophecies may be challenged both individually and collectively, based upon both the structure and content of the prophetic performance. For members, the verisimilitude and reality of prophecy are based on dramaturgical performance, correct procedure, and the process of referential illusion through which prophetic utterances are connected to everyday events in the lives of members. (I988:145)
5. The Political Leader decides what to do with his property, Nigeria. (Photo by Alhaji Sule Dan Sokoto) 
Understandably, these "holy" sociopolitical performances have no written text; a script would be evidence the military government could use to arrest the performer under Decree 2. But there is a general scenario which members know by heart: the introductory music/singing, the didactic/ homiletic element, the confessions/possessions, the asperges/casting out evil, and the concluding music/singing. ${ }^{10}$

The introductory music/singing is often about the oppression, injustice, and deprivation that the people go through, and a calling on God for deliverance. The verses are a litany of grievances with a chorus beseeching the savior to come to the rescue. The singing sets the ground for a harsh sermon by the lead performer against the sociopolitical evils of the day. In the confessions/possessions that follow, people act out their evil past or the evil past of others in a seemingly ecstatic manner. They may speak in "tongues" with some other members interpreting; this is mixed with prophetic utterances. Holy water is then sprinkled on the confessor and on the people to expunge their evil deeds. The ceremony closes with the congregation giving presents, usually money, to the organizers while singing thanks to God for delivering them now and forever. These presents-"offerings" they are called-help sustain the performers materially. The thin line between religion and drama, between ritual and theatre, the "sacred," perhaps salvific nature of the two, and particularly their celebratory and transformative qualities-of which Richard Schechner has written with analytical insight (1976:196-222; $1985 ; 1987: 5-33$ )-come to the fore in these experiments.

\section{Fela}

Music, especially as practiced by the Nigerian musician, Fela AnikulapoKuti (formerly Fela Ransome-Kuti), has also become a part of the perform-

6. Despite popular opposition, the Political Leader takes his beggar's bag to go looking for loans from the $I M F$, the World Bank, the Vatican, and Mecca. The doth that covers his eyes and ears is green-andwhite striped, the colors of the national flag. (Photo by Alhaji Sule Dan Sokoto)

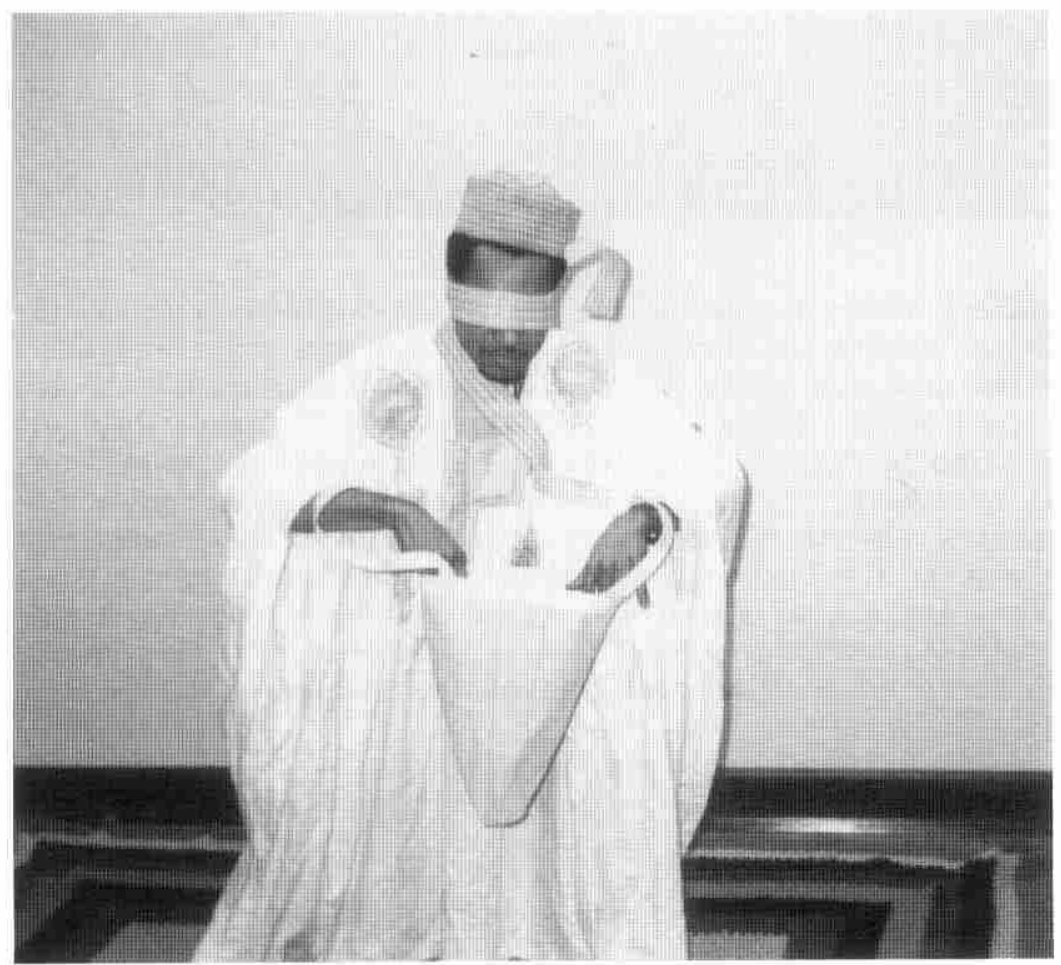


ing arts sociopolitical protests. While the lyrics of such recordings as "Zombie" (1976) and "Beasts of No Nation" (1989) are annoying enough for the military regime of Nigeria-the pervading image is that of the intellectually deficient and animalistic man-of-arms controlling the nation-it is Fela's live performances that drive the regime insane. Fela's live show is both a musical and a verbal attack on the Nigerian government. He always has a large following of student audiences all over the country. At Abeokuta in April 1989 the police forcibly prevented Fela from performing for a student audience of 20,000 .

Twice (in 1978 and 1986) Fela Anikulapo-Kuti has been beaten and jailed for his outspoken attacks on government corruption and police repression. In one savage attack by soldiers in 1978, his house and "shrine"the name of his theatre in Lagos-were razed (Grass 1986:131-48). He has become the rallying point for angry university students and disaffected masses. Not even the fact that his senior brother is the Minister for Health has slowed down his verbal and musical attacks on the present government of Nigeria. In an interview with Fela in London, Jane Bryce observes that songs such as "Beasts of No Nation," with its refrain ridiculing the human rights charade of the military government, have not endeared Fela to President Babangida (1989:12-13). General Babangida used the human rights issue as a justification for seizing power in 1985 from General Buhari, yet this self-appointed apostle of human rights broke up the Nigerian Labor Congress, banned the Academic Staff Union of Universities and the National Association of Nigerian Students, and harasses and jails those leaders whose views differ from his own-Festus Iyayi, Gani Fawehinmi, Tai Solarin, Michael Imoudu. Even the Nobel Laureate Wole Soyinka and members of the National Association of Sea Dogs were forcibly barred from conducting a symposium on the "State of the Nation" in July 1989 in

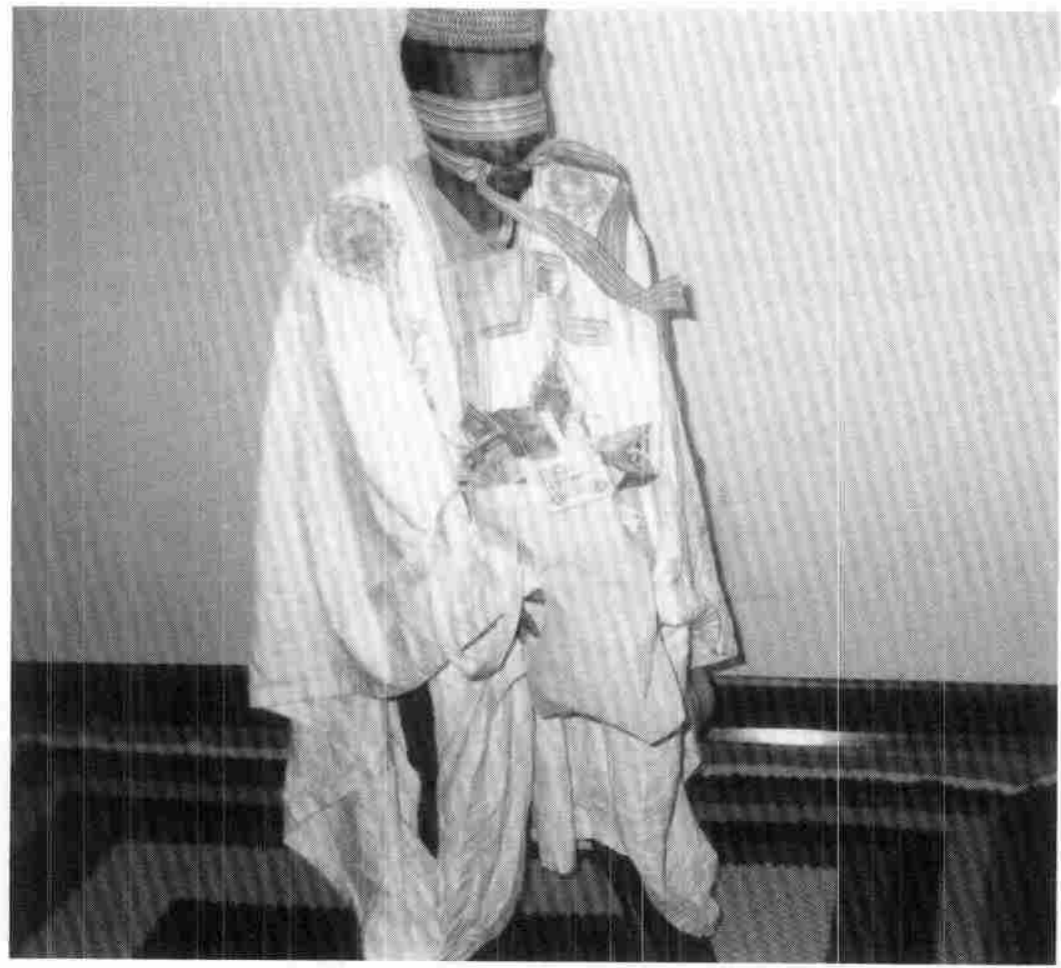

7. The Political Leader retums with a bag full of money from foreign credi. tors. The doth which binds his neck and mouth symbolizes his enslavement to creditors. (Photo by Alhaji Sule Dan Sokoto) 
8. The Political Leader's human face disappears behind a face of money. (Photo by Alhaji Sule Dan Sokoto)

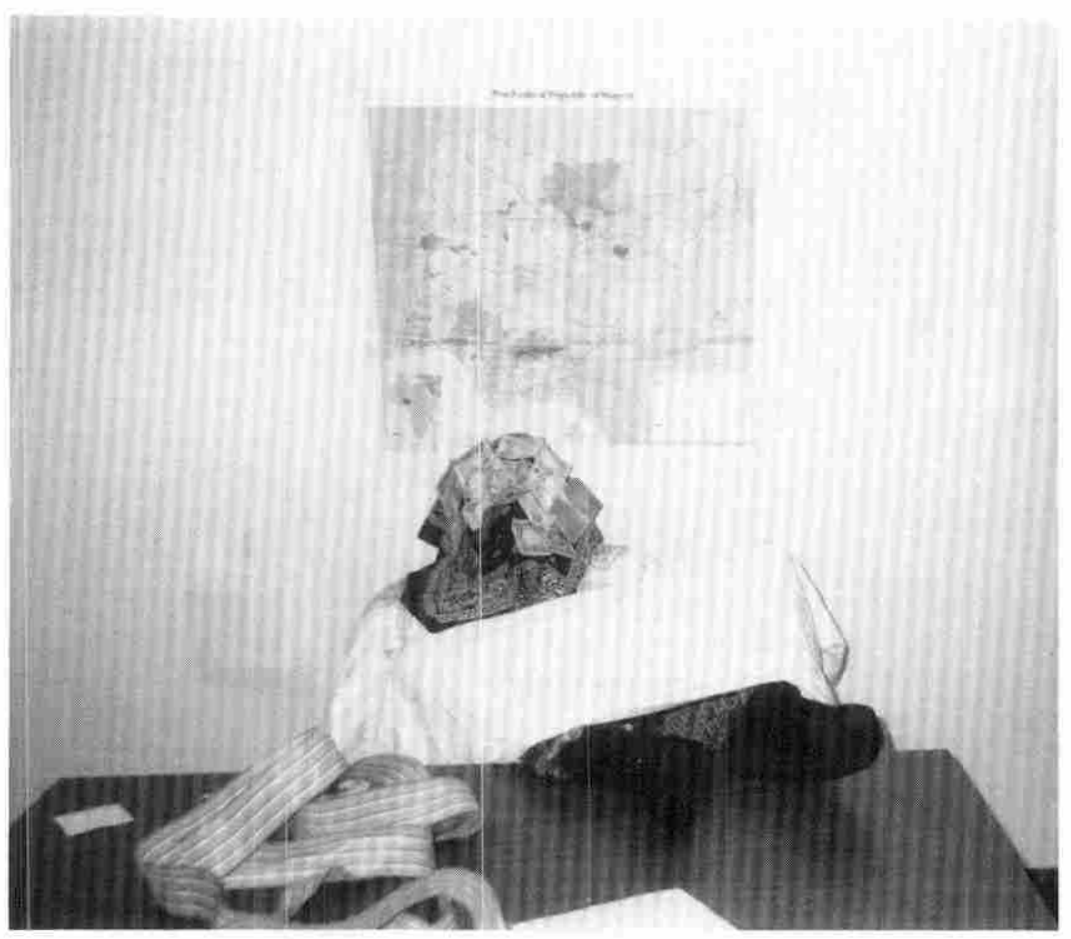

Abeokuta. In 1990 the government announced a plan that would have required official government permission to practice journalism and in May I99I closed down four independent newspapers for their reports on police brutality and the resultant deaths of some students.

Fela points out that his performances and music are geared toward a "major role [of] speaking out against what he sees happening in Nigeria"against poor preparation for civilian rule in 1992, Debt-Equity Swap, against killing people in jail, against police "settle" (bribe) syndrome, and above all, against the human rights violation of that "animal" in power (Babangida) whom he addresses in the song "Beasts of No Nation":

Animal talk done start again:

"Dash them human rights."

How animal go know say they no born me as slave?

How animal go know say slave trade done pass?

And they want dash us human rights [...]

Human rights na my property,

You can't dash me my property.

Refrain:

Animal can't dash me human rights. ${ }^{1}$

(Anikulapo-Kuti 1989)

In a country in which "the mark of the beast"-to use Maja-Pearce's phraseology (1989:14-20)-is a harrowing experience that has driven theatre artists to speak in metaphors when they speak at all, the presence of Fela Anikulapo-Kuti with his direct antigovernment music, satire, and performance is refreshing. 


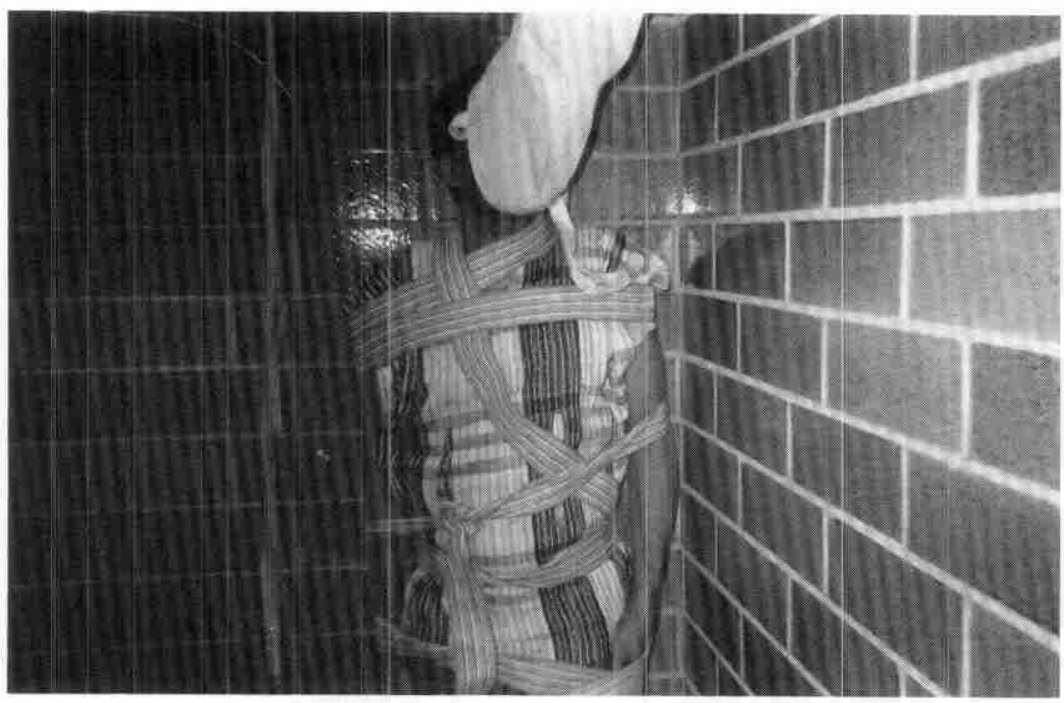

9. An armed robber lacted by Chidi Adamu) is lined up for public execution on orders from the military government. This 1990 living-room performance in Port Harcourt, Nigeria, proposes the same fate for politicians and military leaders who have robbed the nation. (Photo by Chris Kalio)

\section{The ANC-Inspired Experiments}

The southern portion of Africa has for a long time been the battle ground between liberation movements and governments: SWAPO versus Namibia, MPLA versus Angola, FRELIMO versus Mozambique, PAC and ANC versus South Africa. ${ }^{2}$ The various liberation movements have cultural wings under whose aegis theatre is used as a supportive educational and political tool. Says Comrade Chipande, the former FRELIMO chief of the armed forces, while reprimanding some of his troops for lackluster musicmaking: "Not to sing well is a political error" (in Salutin 1979:26). The late President Samora Machel of Mozambique used to perform songs to open sessions of the Assembleia Popular (People's Assembly), and Augustino Neto, late President of Angola, used to write and perform poems. All the liberation movements have since achieved their political objectives, except the PAC and the ANC which are currently working on their sociopolitical agenda in South Africa following President F.W. de Klerk's historic program of reform announced in February 1990.

The ANC, like the BCM (Black Consciousness Movement) which began later, is active in all the arts but in none more effectively than theatre. Mshengu gives reasons why theatre is a crucial area of political activity in the liberation movement. Conventional political action is dangerous. The press, radio, and publishing houses prove vulnerable to censorship and are controlled by the ruling minority in South Africa. Film is financially beyond the reach of the political artist. Theatre, in contrast, is inexpensive, "mobile, simple to present, and difficult to supervise, censor, or outlaw." It is therefore the one medium left to "use to conscientize, educate, unify, and mobilize both cadres and rank and file" (Mshengu 1979:3I-38). 1 shall illustrate with two groups: Refugee Theatre (Tanzania) and Zambuko/ Izibuko (Zimbabwe).

The Refugee Theatre was one of the first ANC-inspired theatre groups and is still functioning today. Following the Sharpeville massacre of 1960 , the declaration of a state of emergency, and the banning of the ANC, Nelson Mandela and Walter Sizulu founded the Umkhonto we Sizwe (Spear of the Nation) as the military wing of the ANC. The savage perse- 
IO. E II. Political theatre performers have turned to religion as an avenue for expression. "They have become seers, prophets, and apostles who, 'pos. sessed by spirits,' are able to dramatize and make sociopolitical statements without government persecution and prosecution." The beaded woman in plate 10 and the woman in the center in plate II are preparing to enter a state of spiritual possession in this 1989 ritual perfor. mance in Oshogbo, Nigeria. (Photo by Ajayi)

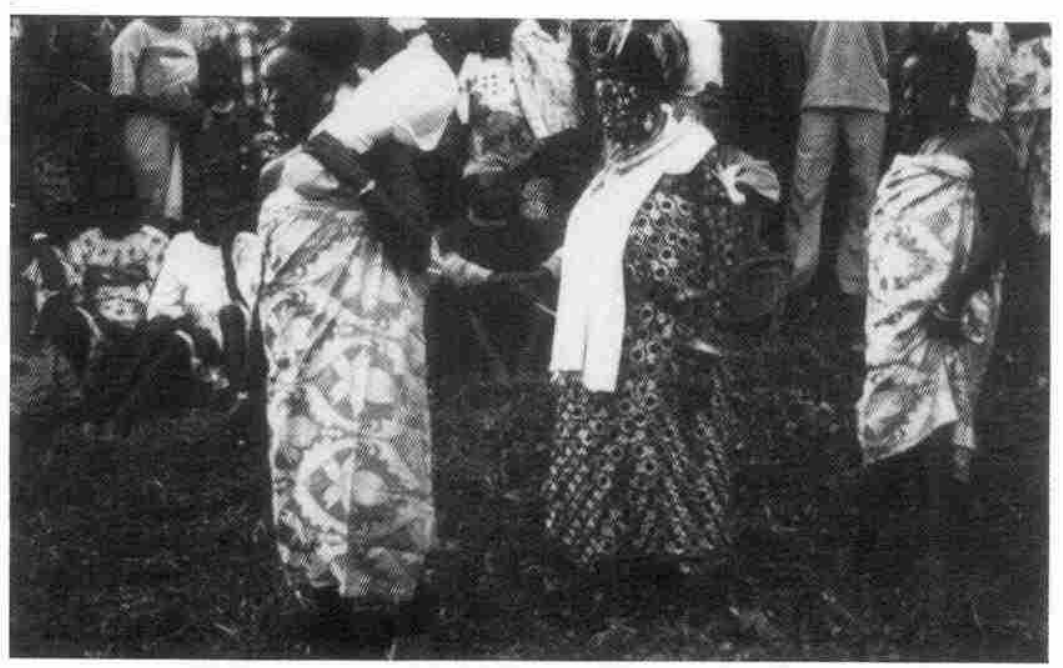

cution engineered by the South African government against protestors and nonconformists which culminated in the Soweto uprising and massacre, led to a stream of young South Africans, mostly blacks, seeking refuge in the frontline states. Most were penniless and found sanctuary in Tanzania but had to wait for scholarships from African nations to continue their studies; others joined the Umkhonto we Sizwe.

The population of the refugee camps of these South African exiles, ages 14 to 20 mostly, was always changing as new escapees from the apartheid system took the place of those who had found places in schools or had joined the Umkhonto. But there was a great need to educate these people both politically and culturally. Theatre in its African tradition of song, dance, dialog, storytelling, and audience participation was the answer. The many experimental plays teaching the history and politics of the ANC and the liberation struggle finally crystallized into a play called Freedom in Our Lifetime, first produced at the refugee camp in Morogoro, Tanzania, in 1978. The play and its film version are still used to teach young ANC members the history of the struggle, which by now none of them are old enough to have experienced.

Like the creations of the Kamiriithu of Kenya, the Samaru of Nigeria, and as we shall see later on, the Zambuko/lzibuko of Zimbabwe, Freedom in Our Lifetime is the result of a democratic experiment. The subject matter was collectively selected, and the storyline broken into eight scenes. The content of each scene was determined, especially how it would begin and end. The play is a mixture of set speeches and improvisation; it was never scripted. Speeches of Nelson Mandela and Albert Lutuli (ANC's 1953 president) are committed to memory and recited with utmost fidelity, but the performers enjoy great freedom in introducing new dialog, much of it comic. But the improvisation usually centers on police brutality and often the staged terror that ensues when a police officer hits a suspect becomes dangerously real. Singing is a strong component of the production and the ten songs in the play are freedom songs composed by the people. They are sung without musical accompaniment. The audience is usually boisterous, singing with the performers and commenting freely on the action. The finale is always the ANC anthem of a liberated South Africa: "Nkosi 


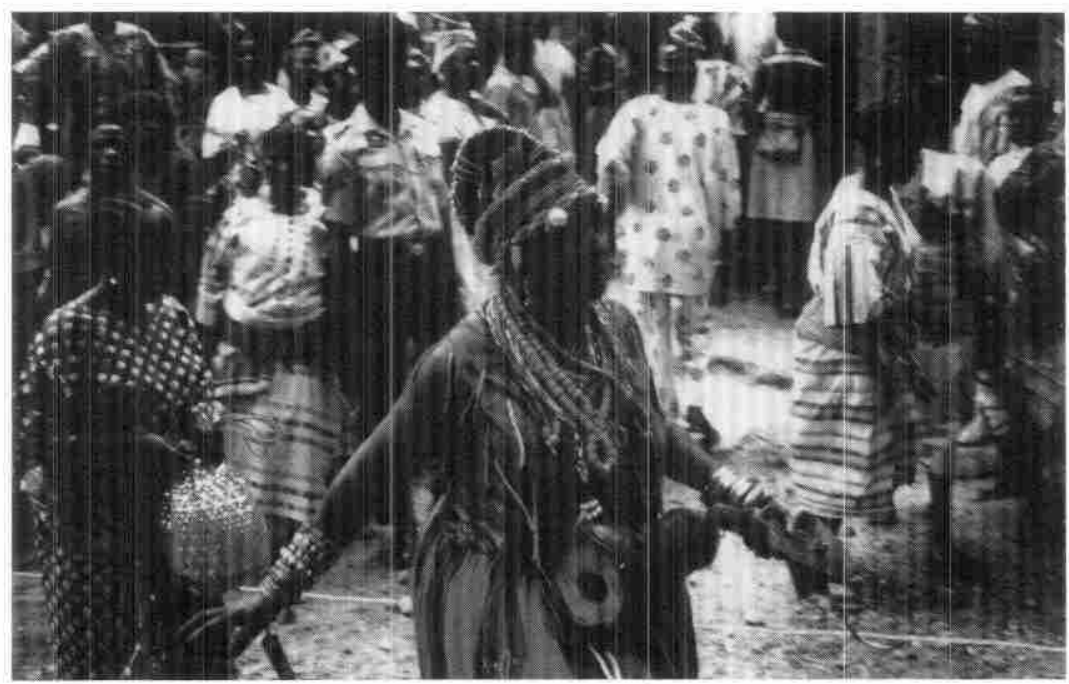

sikelela i-Afrika" (God bless Africa) with performers and audience singing together. The simple staging allows the play to be performed anywhere; the sun provides the necessary illumination and there is no special technical backing required:

There are no sets, no costumes to speak of, and the props are rudimentary and improvised. A table and chairs serve for the indoor scenes, the chairs arranged in a semicircle representing the prison cell, and a door knob is removed from the building to provide the police officer with a revolver. The machine guns are lengths of two-by-four, and when the police open fire on the crowd at Sharpeville the detonations are created by a little boy beating the inside of a tin with a stick.

(Akerman 1978:40)

According to Nana Ngobese, Freedom in Our Lifetime is still being staged in Tanzania. A large group of ANC members, especially the Umkhonto, remains in Tanzania as they wait to see if the 1990 dismantling of apartheid is real. While they hope for the best so that they can return to their country, they know full well that to forget the past is to betray their cause and deaden the will to fight for freedom.

The ANC has a sequel to Freedom in Our Lifetime. Simply referred to as Soweto, the play is woven around 13-year-old Hector Peterson, the first child to be killed in the Soweto uprising of 1976 . Their anger inflamed by staring at the corpse, the young South Africans in the play begin mass demonstrations. More people are killed by the police. An older ANC member who is a military tactician for the Umkhonto advises them to flee the country, to obtain military training and weapons from the Umkhonto. The play ends with the young people getting ready to join the Umkhonto, swearing to come back to meet firepower with firepower. This 30-minute play is said to have made people cry when performed in the Tanzanian capital in 1979 .

There are other examples of ANC-inspired theatrical experiments in many African and European nations. In London the ANC's cultural unit, "Mayibuye" performs poems, songs, and dances. In Zimbabwe a group of 
theatre artists gathered together on their own to mobilize Zimbabweans into solidarity with those struggling to liberate South Africa. The group is called the Zambuko/Izibuko. ${ }^{13}$

Deriving its name from "ford" or "river crossing," Zambuko/Izibuko is an egalitarian, socialist theatre group. To members of the group, theatre is not only a means to "navigate history" but a reliable arsenal in the fight for a society that would be free, peaceful, and just; nonracist, nonsexist, noncapitalist, and nonimperialist (McLaren I992:93). Zambuko/Izibuko has performed such plays as Katshaa! the Sound of the AK (1986), Samora Continua (I988), and Mandela, the Spirit of No Surrender (I990). Its productions are not restricted to Zimbabwe. It has toured most of the frontline states including Tanzania, Zambia, and Mozambique. Katshaa! has been taken to Scandinavia.

From its three major plays it is possible to draw the general characteristics of the group's productions. Casting is never based on race and sex. White actors play black and black, white. Women play men and men, women. All the productions are geared toward articulating vividly and eloquently the social, cultural, economic, and political developments in the frontline states as they are related to or triggered by events in South Africa; it is the strong belief by members of the group that South Africa and its neighbors are locked in one wheel of fortune/misfortune. The plays have a pungwe or ngonjera format. A pungwe is a nocturnal guerilla political meeting marked by cultural activities like songs, dances, slogans, sketches, and political dialog and speeches. An ngonjera is a short performance for a political occasion; it is made up of poetry, dialog, dance, and song. Invariably in each play, a nostalgic or emotional reference is made to the history of the country where the production is taking place, and this becomes the transition or the trampoline to leap to the South African problem which is central to the production (McLaren 1992).

Zambuko/Izibuko productions are often multimedia and didactic. Posters, reading materials, stickers are often distributed at performances, and speakers invited to address the audience before performance. The ANC cultural wing helps teach the South African songs in the productions and sometimes supports the group financially. Members of the group follow a democratic process in the making of the plays-everybody helps with the artistic and subject matters of the productions. The technical aspects of production are equally simple so that the plays can be performed in any available space-schools, mines, beer halls, shopping centers, and canteens. The main emphasis is on clarity of message.

Zambuko/Izibuko has not been without its problems. As an avowedly political theatre group, it has faced antagonism from those opposed to its ideology, and especially to its intense relationship to the ANC. Opposition has come in different forms: from the state security forces of Zimbabwe, from government-controlled academic institutions, from the penetrating influence of the South African government, from ZACT (Zimbabwe Association of Community Theatre), and from internal dissension in the group. All these would have brought the death of the group in 1990 but for the resilience of some of its founders and the unequivocal ANC financial and moral support.

\section{The Future}

Gazing into the crystal ball, one can see the longevity, and perhaps immortality, of political theatre in Africa. It is a theatre whose form will 
change rapidly as the world's second largest continent grapples with its numerous political, economic, and social problems. In adjusting to these problems, numerous experiments will emerge helping to vitalize and extend the frontiers of African theatre. The theatre will keep on demonstrating its relevance to the community, a relevance that is beyond the pleasure principle of illusionistic theatre. "The artist has always functioned in African society as the record of the mores and experience of his society and as the voice of vision in his own time" (Soyinka 1975:30).

The ANC-inspired experiments like the Refugee Theatre of Tanzania and Zambuko/Izibuko of Zimbabwe whose theatrical appetite is fed by resistance to apartheid, will evolve to be relevant to a free, multiracial, truly democratic South Africa. But that very freedom will bring new problems. These signs of change are already visible in the Zambuko/Izibuko. Since the release of Mandela and the abolition of some particulars of apartheid, the Zambuko/Izibuko is shifting from the ANC and frontline state political problems to the immediate sociopolitical situation in Zimbabwe. When the ANC leaves finally for South Africa and its financial support ends, the immediate problem for the group will be one of survival (see McLaren 1992:III). If the Zambuko/Izibuko treats these issues, especially the political persecutions within Zimbabwe itself with the same fervor that energizes its ANC-inspired plays, its future will be exciting but ominous: most African governments have little or no tolerance to adverse portrayals and criticism. Zambuko/Izibuko may, like its former ANC mentor, be bitterly persecuted. It may find itself in exile.

The ANC Refugee Theatre in Tanzania, like the other ANC politicocultural groups, will undergo a fundamental readjustment when it returns to a liberated South Africa. It may even cease to be. An independent group of theatre talents not confined to the political didacticism and doctrinaire attitudes of the persecuted will emerge. Theatre groups in a free South Africa will be challenged by the immense situations that freedom itself generates. Political theatre artist in South Africa must contend with inter- and intra-political confrontations, inter- and intra-racial problems, and class antagonisms generated by the tensions between sprawling poverty and skyscraping wealth.

The greatest challenge will be how South African political theatre groups direct their talent to postapartheid reconstruction, to politically humanize those who have been politically dehumanized. The same didactic vitality used to inflame the wrath and passion of death-affirming Umkhonto we Sizwe will have to be redirected to healing the wounds. The ANC is already looking ahead to the role the arts will play in a renascent South Africa. The guerilla form of theatre, the theatre of protest, of resistance and of self-pity, will give way to a rich political theatre that does not depend on repetitive, impoverished criticism where the opposition between bad and good is so obvious and "the range of themes [...] narrowed down so much that all that is funny or curious or genuinely tragic in the world is extruded" (Sachs 1991:I87). Says Albie Sachs, member of the Constitutional and Legal Department of the ANC:

ANC members are full of fun and romanticism and dreams; we enjoy and wonder at the beauties of nature and the marvels of human creation, yet if you look at most of our art and literature you would think we were living in the grayest and most somber of all worlds, completely shut in by apartheid. It is as though our rulers stalk every page and haunt every picture; everything is obsessed by the oppressors and the trauma they have imposed. (I991:188) 
The political theatre of the future will teach a South Africa of diverse cultures to explore-as did a Mozambican poet and former FRELIMO guerilla, Jorge Rebelo-the meaning of the slogan, "Black is Beautiful, Brown is Beautiful, White is Beautiful."

As for the Kamiriithu experiment, it will remain an underground movement until the political situation in Kenya changes. Since the church is a powerful institution in Kenya, the theatre may borrow from Nigerian experiments in which theatres have used the external paraphernalia of the church to produce plays that otherwise would be censored. But in the immediate future, the Kenyan theatre will thrive surreptitiously in drinking halls, market places, and abandoned houses by employing guerilla tactics in production. It will also survive in political dance dramas, songs, and "acts without words."

In Nigeria, where Decree 2 has put the country in an undeclared state of emergency, the present is bleak but the future is bright for political theatre-the military are supposed to hand power back to elected officials in October 1992. The liberation from military censorship will unleash a pentup creative energy in which the political theatre, examining its recent past, will give birth to new experiments. Current underground experiments in living rooms and bedrooms may become an established part of future political theatre productions. Street theatres will rise again and extend to parts of the country they have never been. For now, serious antigovernment theatre must disguise itself as prophecy and possession, poetic recitation, and the Afrobeat satire of the irrepressible Fela.

\section{Notes}

1. Hubert Ogunde's Bread and Bullet, for example, was banned by the authorities because it was thought powerful enough to incite citizens against the colonial administration. Ogunde was also fined six British pounds.

2. Franz Fanon, social theorist, philosopher, and psychoanalyst, is reputed for his theory of liberation from colonialism and his anti-French involvement in the Algerian war for independence.

3. Hubert Ogunde who had earlier on suffered in the hands of the colonial administration now found himself in a similar predicament with the independent government in Nigeria when his theatre, the Ogunde Concert Party, was banned.

4. Ngugi wa Thiong'o is accused by the Kenyan Parliament of founding the Mwakenya movement (before he went into exile), a charge that Gakaara wa Wanjau, a Kenyan artist, was forced to corroborate under torture. Mwakenya began a few months after the Kamiriithu Theatre was destroyed by the government (Sicherman 1990:16, 95; Mkhatshwa 1989:72 and 1990:65-67).

5. In 1986 Florence Adetoun Oni, a participant in Soyinka's group, called for a renascent Guerilla Theatre in Nigeria that would use the Yoruba language. A Yorubalanguage theatre was never realized.

6. In his paper "Using Indigenous Structures for Mass Social Transformation in Nigeria: The Theatre Approach," Tar Ahura points out that the Bakolori Dam Project of the Sokoto River Basin is a Federal Government of Nigeria project aimed at inspiring agricultural production in the country. Farmlands were taken from the farmers for the project with a promise of compensation. The compensation came through the state government and was fraudulently handled by government officials. The farmers lost their patience and went on a rampage. The federal government sent in troops and hundreds of the farmers were shot to death (in Ikperikpe 1987:75-77).

7. Closure of institutions is not limited to universities. On 29 May rogr, four Nigerian newspapers were shut down by armed policemen and their editors and some journalists arrested, on the order of the Governor of Lagos State, for reporting that 
two students were killed in a clash between the police and students of the Yaba College of Technology, Lagos, 28 May 1991. The papers were only opened again for publication in October 1991 (Graham-Yooll 1991:54).

8. This is not an entirely new phenomenon in Nigerian theatre. For example, Bori (members of a pre-Islamic Hausa animist cult) have held public performances in Nigeria in periods of national crisis. In an open area, male musicians who are specialists in the theme-melodies of spirits and jinns sit at one end of the "theatre." When the musicians begin to play the song of a particular spirit, the costumed woman associated with the spirit moves into the performance area and dances. Soon she assumes the demeanor of the spirit possessing her and makes utterances. During the nationalist fervor of the 1950s the Bori had an explicit political wing charged with winning female membership for a particular political party. Details of this are in my forthcoming book Socio-Political Theatre in Nigeria.

9. My own play, It Happened to a Blind Beggar (produced in 1987 at the King's Garden Hotel, Jattu, but as yet unpublished) explores this theme. There was an actual occurrence in Benin City, Nigeria, in which a high court judge of the federal government, Justice Ikomi, was accused of killing and taking away some of the organs of a police officer sent to guard him. Justice Ikomi was suspended by the government until an investigation cleared him.

10. It is interesting to note how the general scenario resembles and yet differs from Jules-Rosette's observations elsewhere in Africa. She gives a five-component scenario in the following order: confession, prophecy, preaching, singing, faith-healing (1988:142). Perhaps the difference is traceable to the more conscious sociopolitical nature of performance in Nigeria.

11. In order to reach the widest audience in Nigeria, most of Fela's songs are written in Pidgin English. In free translation the song would read:

The animal has been making noise again:

"Give [as an example of magnanimity] them human rights."

How will it ever dawn on this animal that I wasn't born a slave?

How will this animal ever realize that the era of slave trade is long gone?

And they want to give us human rights [from the generosity of their heart ...]

Human rights belong to me;

You don't have the authority to give me what is mine by nature.

You can't give me [as a gift] what naturally belongs to me.

Refrain:

An animal cannot give me human rights.

12. SWAPO-an acronym for South West Africa People's Organization; MPLA-Popular Movement for the Liberation of Angola; FRELIMO-Front for the Liberation of Mozambique; PAC-Pan Africanist Congress; and ANC-African National Congress.

13. See Robert McLaren's "Theatre on the Frontline: The Political Theatre of Zambuko/Izibuko" (1992:90-114); and Peter Larlham's "Theatre in Transition: The Cultural Struggle in South Africa" (1991:200-211). Larlham and I had an invaluable exchange of ideas at the Annual Meeting of the American Society for Theatre Research, Seattle, WA, 1991.

\section{References}

Ahura, Tar

1986 "Using Indigenous Structures for Mass Social Transformation in Nigeria:

The Theatre Approach." Sonulus Information 4, (no. 11):14.

Akerman, Anthony

1978 "Refugee Theatre in Tanzania." Theatre Quarterly 8 (no. 30):36-4I.

Anikulapo-Kuti, Fela 
1989 "Beasts of No Nation." Beasts of No Nation. LP. London: EMI Records.

Azad, Ahmed

I988 "Africa: Notes \& Comment." The African Communist I I 2:61-69.

Bryce, Jane

1989 "Fela Anikulapo-Kuti." Index on Censorship 18 (no. 9):12-13.

Eyoh, Hansel

1984 "Trends in African Theatre: The Popular Theatre Approach." Unpublished paper presented at the International African Oral Literature Association Conference, Budapest.

Freire, Paulo

1972 Pedagogy of the Oppressed. Harmondsworth: Penguin.

Graham-Yooll, Andrew.

1990 "Index" [on Kenya]. Index on Censorship I9 (no. 9):38.

1991 "Index" [on each nation]. Index on Censorship 20 (no. 9):37.

Grass, Randall F.

I986 "Fela Anikulapo Kuti: The Art of an Afrobeat Rebel." TDR 30, no. 1 (T 109): 13 I-48.

Ikperikpe, Maris Ngozi

1987 "Popular Theatre as a Tool for Social Transformation in Nigeria: The Northern Nigeria Example." Unpublished manuscript.

Irele, Abiola

I98 $\mathrm{I}$ The African Experience in Literature and Ideology. London: Heinemann.

Jules-Rosette, Bennetta

1988 "Prophetic Performances: Apostolic Prophecy as Social Drama," TDR 32, no. 2 ( $\left.T_{1} 18\right): 140-159$.

Larlham, Peter

1991 "Theatre in Transition: The Cultural Struggle in South Africa." TDR

35 , no, I $\left(\mathrm{T}_{12} 29\right): 200-2 \mathrm{II}$.

Maja-Pearce, Adewale

I989 "The Mark of the Beast: Nigeria in the Year 1989." Index on Censorship I8 (no. 9):14-20.

1990 "Women in Africa." Index on Censorship 19 (no. 1):19-20.

McLaren, Robert Mshengu

1992 "Theatre on the Frontline: The Political Theatre of Zambuko/Izibuko." TDR 36, no. I ( $\left.T_{133}\right): 90-\mathrm{II}_{4}$.

Mkhatshwa, Jabulani

1989 "Africa: Notes \& Comment." The African Communist 1 16:65-75.

1990 "Africa: Notes \& Comment." The African Communist 123:62-67.

Mshengu

1979 "After Soweto: People's Theatre and the Political Struggle in South Africa." Theatre Quarterly 9 (no. 33):31-38.

Mugo, Micere Githae

1990 "Women in Africa." Index on Censorship 19 (no. 1):19-20.

Ngugi, wa Thiong'o

$198 \mathrm{I}$ Detained: A Writer's Prison Diary. London: Heinemann.

1983 Barrel of a Pen. Trenton, N]: Africa World Press.

1986 Decolonizing the Mind. London: James Currey Ltd; Nairobi: Heinemann.

Ogunbiyi, Yemi

1981 Drama and Theatre in Nigeria: A Critical Source Book. Lagos: Nigeria Magazine. 
Oni, Florence Adetoun

I986 "Let the Theatre Go Guerilla." Prime People I (no. 16).

Sachs, Albie

I991 "Preparing Ourselves for Freedom: Culture and the ANC Constitutional Guidelines." TDR 35, no. I (T129):187-193.

Salutin, Rick

1979 "The Culture Vulture in Mozambique," This Magazine I3 (no. I):26-30.

Sartre, Jean-Paul

I963 Black Orpheus. Paris: Editions du Seuil.

Schechner, Richard

1976 "From Ritual to Theatre and Back." In Ritual, Play, and Performance, edited by Richard Schechner and Mady Schuman, I96-222. New York: Seabury Press.

1985 Between Theater and Anthropology. Philadelphia: University of Pennsylvania Press.

I987 "The Future of Ritual." Journal of Ritual Studies I (no. I):5-33.

Sicherman, Carol

1990 Ngugi wa Thiong'e: The Making of a Rebel. London: Hans Zell Publishers.

Soyinka, Wole

I975 "The Writer in a Modern African State." When the Man Died, edited by John Agetua, 25-30. Benin City: Bendel Newspapers Corporation.

Ukpokodu, I. Peter

1992 Socio-Political Theatre in Nigeria. San Francisco: Mellen University Research Press.

I. Peter Ukpokodu is an Assistant Professor of theatre and of African-American studies at the University of Kansas-Laurence. He is the author of Socio-Political Theatre in Nigeria (Mellen Press, 1992) and a contributor to the forthcoming African-American Encyclopedia (Salem Press). His poems and articles have been published internationally.

\section{TDReadings}

TDR has recently published several articles on political theatre in southern Africa. See Caleb Dube's "Amakhosi Theatre," vol. 36, no. 2 (TI 34), Summer I992, Robert Mshengu McLaren's "Theatre on the Frontline," vol. 36, no. I (TI33), Spring I992; also see Albie Sachs, "Preparing Ourselves for Freedom," Carol Steinberg, "Albie Sachs: Our Shakespearian Fool," and Peter Larlham, "Theatre in Transition: The Cultural Struggle in South Africa," all in vol. 35, no. I (T129), Spring 1991. See also T. Philemon Wakashe's two articles on Matsemela Manaka in vol. 30, no. 4 ( $\left(\mathrm{T}_{1}\right.$ I2), Winter I986. See also "The Zandile Project: A Collaboration between UT, Carpetbag Theatre, and South African Playwright Gcina Mhlophe" by Patrick Kagan-Moore, vol. 34, no. I (T125), Spring 1990. 
Copyright of TDR: The Drama Review is the property of MIT Press and its content may not be copied or emailed to multiple sites or posted to a listserv without the copyright holder's express written permission. However, users may print, download, or email articles for individual use. 